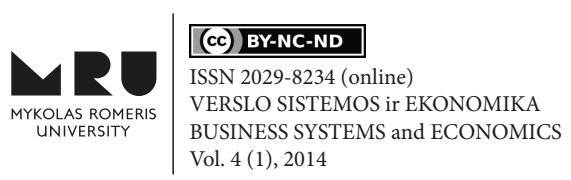

\title{
PROJECTION AND IMPLEMENTATION OF TOTAL QUALITY MANAGEMENT SYSTEMS WITHIN THE TEXTILE PRODUCTION
}

\author{
Elizabeta MITREVA \\ Goce Delčev University \\ Faculty of Tourism and Business Logistics \\ Krste Misirkov No.10-A, P.O. Box 201, Štip, Republic of Macedonia \\ E-mail: elizabeta.mitreva@ugd.edu.mk \\ Nako TASKOV \\ Goce Delčev University \\ Faculty of Tourism and Business Logistics \\ Krste Misirkov No. 10-A, P.O. Box 201, Štip, Republic of Macedonia \\ E-mail: nako.taskov@ugd.edu.mk \\ doi:10.13165/VSE-14-4-1-02
}

\begin{abstract}
In this paper, the need to design and implement a system of total quality management (TQM) in the "Textile-logistics center", which deals with service activity in the textile industry in Macedonia, is being elaborated and confirmed. Quality should be sought not only within the production process and products, but also in all segments of the business processes, even in the employees' manner behavior. Based on the conducted analysis of the existing quality system, an appropriate methodology has been designed for each feature of TQM philosophy. In order to design the quality system, the QC-CE-Pyramid model has been applied, according to which the system should be realized through the Deming's circle (PDCA), as well as the Ishikava approach (i.e., who, what, when, where), which fits the pyramid hierarchy of the company. Through the QC-CE quality model, the obligations and responsibilities of all employees have been defined. Thus, rules of conduct as well as good interpersonal relationships have been established. The application of the methods and techniques for faultless operations has provided both greater efficiency and effectiveness in the company. The benefits from the use of the methods and techniques resulted in meeting the needs of the customers, strengthening the company's place at the market, employees' satisfaction, as well as improvement of the community.
\end{abstract}

Keywords: quality, TQM philosophy, QC-CE model, Pareto diagram, Ishikava approach. JEL Classification: $\mathrm{O} 32, \mathrm{O} 33$. 


\section{Introduction}

At a time of great economic turbulence and change, any company that wants to survive, be stable and continuously improve the business processes needs to build its own quality system (Evans, 2005). The effects of the changes in the environment of the company will trigger changes in its technology and production, as well as application of total quality management, by acquiring knowledge, skills and provision of knowledge-based development (Van der Wiele and Brown, 1997). The application of the TQM (Total Quality Management) strategy in a company means improving quality by examining their business processes by defining, designing and optimization of the cost of quality (Bhagwat and Sharma, 2007). The model quality system (see Figure 1) can be presented by "the house of quality" (Mitreva, 2011).

Figure 1: Integrated methodology for designing and implementation of the TQM system in the company

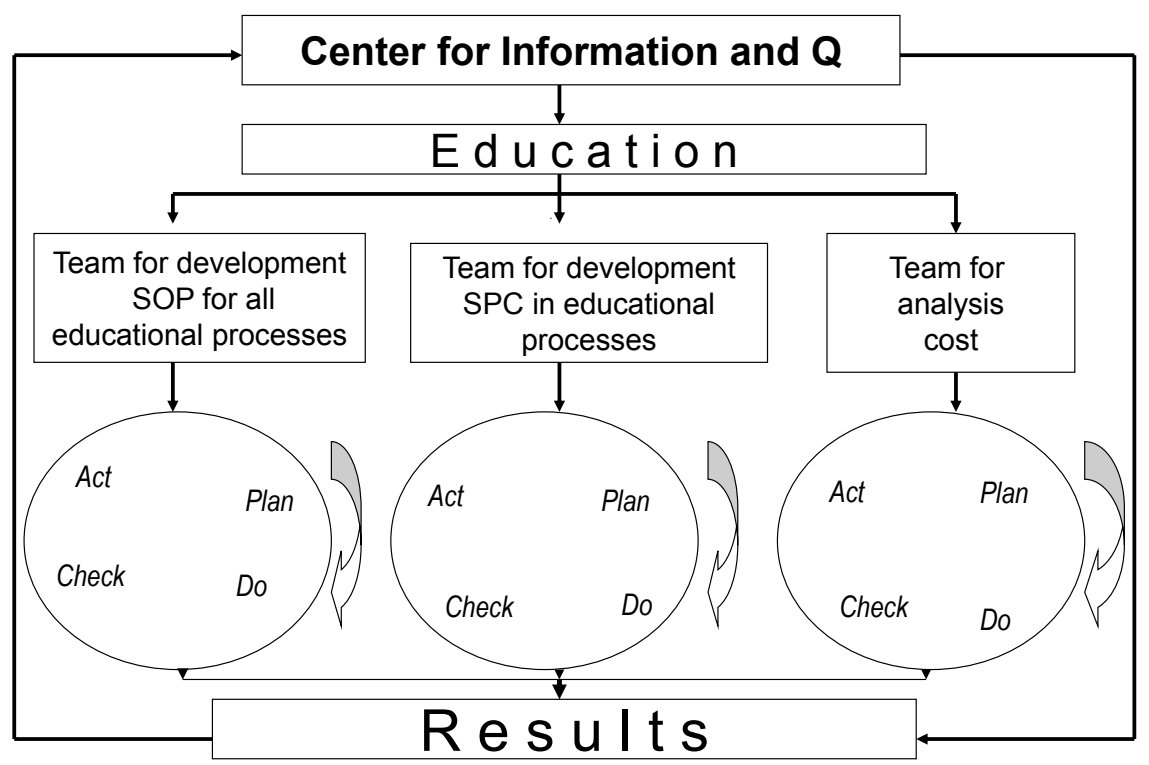

Source: Mitreva, E. (2011)

At the core of "the house of quality" are the measuring results, evaluating, analyzing and comparing the quality or lack of quality. Metrology is the basis for measuring the quality system. Measurement in production processes must be present at all production stages because it is the only way the level of quality can be known. The measurement starts with the input of raw materials, continued measurement of semi-finished products, and ends by measuring the properties of finished products. Moreover, the time of the technological process, the time of the production process and the standard productivity of the worker are all measured. 
One of the pillars of "the house of quality" is standardization. The internal standardization of all phases of work, construction, procurement, production and quality control are of fundamental importance. The standards are the language of raw materials, products and processes, operations and organization quality. By using the standards, working order and proper communication among employees is achieved.

Daily practice of employees using various methods and techniques of non-defect operation ensures stability of the processes and detection, as well as prevention of defects in the workplace.

In order to achieve good quality, quality education and training for the staff is necessary. The purpose of education is to build knowledge and awareness of the employees to perform their tasks more efficiently. The training is carried out according to the needs of the staff, compliance with their qualifications. In order to achieve and enhance the quality, motivation is needed. It is necessary to develop awareness among employees that everybody is responsible for the quality.

Each company is required to optimize its costs. Costs directly affect the formation of the price of the product. If costs are optimized, it may improve the company's reserves. Practice has shown that the errors and their corrections are costly for industry. Therefore, the non-defect operations are preferred by the management. Management is the roof of "the house of quality" and it needs to lead and protect the company.

The success of the business processes today cannot be imagined without the use of IT computer systems (Mitreva et al., 2013). The computer systems by its hardware and software content are the basis for rapid transmission of information for implementation of business processes. They are always connected with the answers of the questions what, who, how, where, when, and also related to the question who is responsible for completing the work in the enterprise. Through them, getting data for the development of standardization, non-defect production, cost analysis, which are the basic pillars of the system with the total quality management (TQM). Today, these data is stored in organized forms and packages (databases), which are computerized, searchable and useable at any time, for any working position, in order to achieve efficient operation. The interconnection of business processes of the enterprise network information systems means a complete quality prioritization.

\section{The need to design a quality system in Macedonian textile companies}

According to expert analysis, the textile industry is an important economic factor in the Macedonian economy because 30 percent of the value of total exports is being created by this very industry and also by the fact that it employs more than 22000 people.

Apparel companies in Macedonia are mostly dealing with loan production and basic values are seeking fast and quality delivery of the orders and thereby taking into account the cost and meeting the requirements of the customers (Mitreva et al., 2012). Thus, Macedonian apparel does not require anything other than effectiveness and efficiency, i.e., rapid preparation and production of the work order. The implementation of these activities is necessary to define business processes and determine the values of the parameters and variables of the system.

The opening of the "Textile-logistic center in Macedonia" is an important step in helping the Macedonian textile production in the direction of following the world trends, meet 
deadlines and cost optimization. The main activity of the center is producing a prototype, making cutting strips, plotting and automatic cutting. The creation of this center is supported by the U.S. Agency for International Development (USAID) and a private company from Shtip. The center was created with the intention to offer small and medium textile enterprises in Macedonia new types of services through the option of using the latest technology and software in the fields of design and production support of computer systems.

The activities of the computer support center for the apparel companies are realized through CAD (Computer Aided Design) - CAM (Computer Aided Manufacturing) service as a necessary link to effective production.

\section{Basis for the design and implementation of the quality system in CAD-CAM textile production}

For the efficient operation of the quality system introduced by ISO 9000:2008 in the "Textile-logistics center", in order to access certain information, such as plans and methodology for their implementation, the standard operating procedures (SOP) are required for all business processes, rules of operation, regulations, textile standards, matrix of duties and responsibilities, records for quality control of data, proposals for corrective actions, etc. Therefore, it is necessary to design a good information system (Kulp et al., 2004).

The company has an information system introduced before the TQM system and it works as follows. The service carried out by the "Textile-logistic center" is a CAD-CAM service. For this service, one needs a high tech equipment of software packages (systems), digitizers, plotters, and computer cutting machine (cutter).

In order to fit with the new trends, the "Textile-logistic center" is necessary to continuously enhance the business processes for CAD-CAM production. The center began working with one computer station, a plotter, a digitizer and a cutter. As the needs of the market and the company grew steadily, it was modernized. Today, the company has seven computer stations and three plotters for high speed printing, generating new staff and conducting training for new skills for independent work. In this way, the employees have a direct access to information, that each of them is a receiver, provider and recipient. Also, there is a daily flow of knowledge and information.

This information system is constructed and provides high quality data management, but the problem is that the information do not come in time, but are delayed and have a reduced ability to intervene during the business process. In order to shorten the time of the transfer of information and increase efficiency in operations, a system of total quality management should be introduced (Mitreva et al., 2013).

\section{Analysis of the current state of the "Textile-logistic center"}

The current situation in the "Textile-logistic center" can be analyzed through the four pillars of "the house of quality": internal standardization, methods and techniques for providing quality, education and motivation, and cost analysis of quality. The current situation is analyzed through the criteria for the European Quality Award: leadership, policy and strategy, management of staff, resources, processes, customer satisfaction/users, employee satisfaction, impact on society, business results. Through these criteria, the current standing 
was evaluated, presuming that the company was competing for the European Quality Award (European Foundation for Quality Management - EFQM).

Based on the detailed analysis of the current situation, the "age" was determined, i.e., the development of the "Textile-logistic center" (see Table 1) in the pillars of "the house of quality" (the young and poor system towards mature and developed system, and vice versa).

The deviations of the subsystems of the TQM system symptoms through the "health" of the quality system were considered and the conclusion was the following (see Table 1).

Table 1: Development stages of the TQM in the "Textile-logistic center" on the pillars of "the house of quality"

\begin{tabular}{|c|c|c|c|c|c|}
\hline \multirow{8}{*}{ 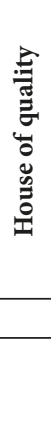 } & \multicolumn{5}{|c|}{ Development stages in the "Textile-logistic center" } \\
\hline & & Beginner & Intermediate & Upper-intermediate & Advanced \\
\hline & $\begin{array}{l}\text { Internal } \\
\text { standardization }\end{array}$ & & & $\bullet$ & \\
\hline & $\begin{array}{l}\text { Methods and } \\
\text { techniques for } Q\end{array}$ & & $\bullet$ & & \\
\hline & Education & & $\bullet$ & & \\
\hline & Motivation & & & $\bullet$ & \\
\hline & Costs & & & $\bullet$ & \\
\hline & $\begin{array}{l}\text { Measurement, } \\
\text { evaluation and } \\
\text { analysis }\end{array}$ & & $\bullet$ & & \\
\hline
\end{tabular}

Source: “Textile-logistic center" (2012)

Based upon the results of the survey, it was found that the "Textile-logistic center" cares about the quality of products/services through the established quality system. However, insufficient attention is given to the continuous education and training of the employees to acquire new skills, and there are poor investments in innovation, while the work in a team is considered a return to the past. The company pays attention to the employees, customers, suppliers and the community, but has a weak application of statistical process control (SPC) a state found in most of the Macedonian textile companies resulting in many errors, delays and complaints. Analyses have shown that the existing information system provides good quality of data management. Yet, the problem is that the information does not come in time, but is delayed, and there is a reduced ability to intervene in time within the business process.

Based on the results, it was concluded that the "Textile-logistic center" is moving things in the right direction in terms of other Macedonian companies, but to be the center of "world class" it is necessary to design and implement a system for total quality management.

\section{Designing a system of total quality management in CAD-CAM textile production}

The introduction of the TQM strategy in an enterprise requires a proper methodology for each function. Starting from this basis, the system established in the textile center with corrections and amendments to it through the QC-CE-Pyramid model approach, improving its efficiency and effectiveness, was analyzed. 
The design of the quality system has applied the QC-CE-Pyramid model (Mitreva and Filiposki, 2012), according to which the system should be processed through the Deming's circle (PDCA) and the Ishikava approach: whom, what, where, who is responsible in the pyramid hierarchy of the company (see Figure 2).

Figure 2: Use of the QC-CE-Pyramid model in building information systems for quality

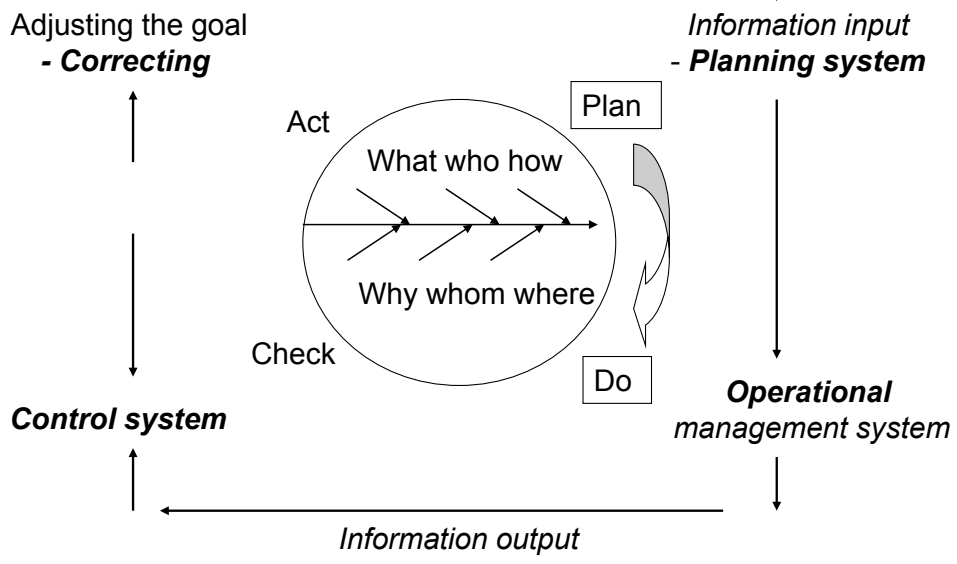

Source: Mitreva, E. and Filiposki, O. (2012)

Through the QC-CE quality model (Mitreva and Filiposki, 2012), the obligations and responsibilities of all employees are defined. In that way, rules of conduct and good interpersonal relationships are achieved. Through this model, the standardization of all business processes across the enterprise is being achieved, via standard operating procedures in the form of current cards. The standard operating procedure begins with planned activities and baseline inputs and it continues with the activities of the business process, and each stage receives output information that is input for the next stage. In the end, the business process ends with information, which is the result. This achieves vertical and horizontal connectivity between employees according to the structure of the pyramid. Thus, ensuring quality in the company, followed by the information, is in accordance with standard operating procedures.

The circle closes with correcting and answering the questions what, whom, where, when, who, which provides information with complete supporting documentation with specified quality, obligations and responsibilities. In order to achieve an effective quality system, it should be both defined and well documented (see Figure 3). 
Figure 3: A flow chard of standard operating procedure in CAD-CAM textile production

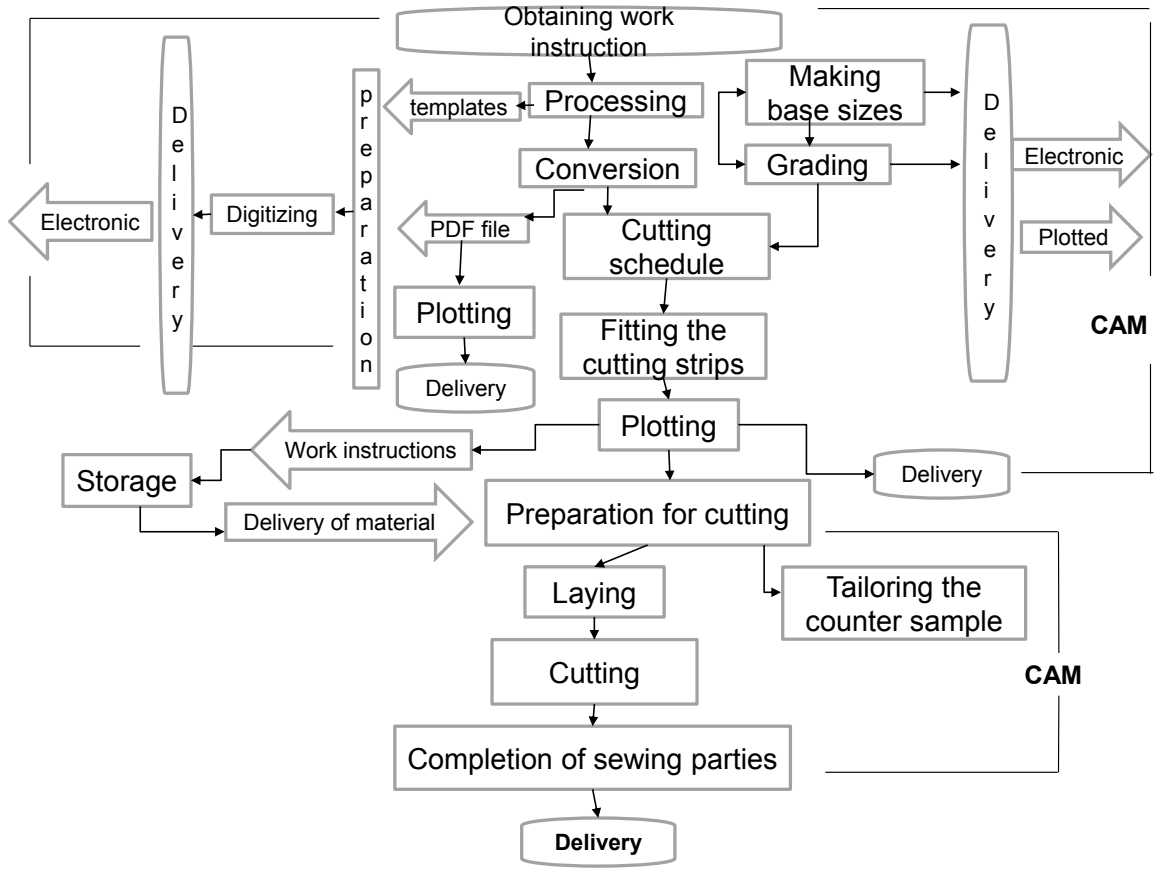

Source: “Textile-logistic center” (2012)

Because the quality system defines the obligations and responsibilities of all employees through this mode of transmission of information, it can provide complete care for quality.

The design of standard operating procedures must apply appropriate methodology methods and techniques of statistical process control, as well as non-defect production methodology for optimizing the costs. These methodologies are offered as support for the top management, acquired for displaying the results of the implementation of methods and techniques in this company, as well as involvement and commitment of every employee. The most important segment in the preparation of templates is their development with great accuracy. Therefore, constant measuring and evaluating is necessary for controlling the plotters with their frequent calibration and performance of test-plotting (as daily operational procedure).

\section{Analysis and review of information from designing a system of total quality management in CAD-CAM textile production}

The company implemented part of the methods and techniques for non-defect operations, such as Check cards, Map of trend, Pareto approach and Ishikava method in some of the business processes (Dale and Lascelles, 2007). The measurements and analysis found irregularities regarding the accuracy of patterns, time of production, quality and time of delivery, so a "sample room" was projected, in order to improve the quality of making patterns, 
which lead to other benefits and have also increased the reliability of the designers in their work (from paper to a real piece of clothing).

Using the Ishikava diagram for the analysis, it can be seen what the critical place for the reasons of errors in the produced templates at the "Textile-logistics center" is (see Figure 4).

Figure 4: Application of the CE diagram for determining the causes of errors of the produced templates

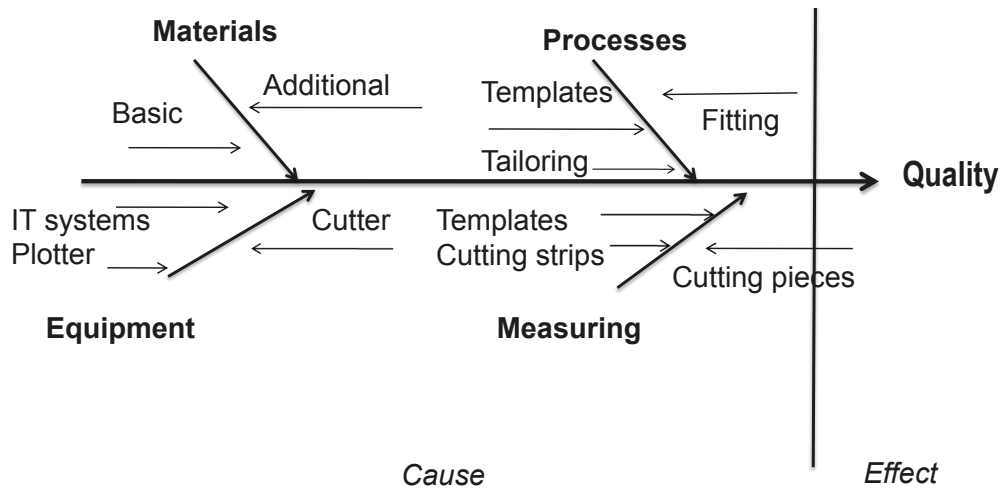

Source: “Textile-logistic center" (2012)

By analyzing the CE diagram, the emphasis is put on the "process" or places, where changes need to be made to improve the characteristics of quality through the design control system in all key stages. To avoid even the smallest errors on the quality of the piece, a "sample room" (room for sewing samples) has been created. This section sews a sample in the presence of the modeler to perform measurement and evaluation, and all that is missing or is defective will be repaired.

The application of methods and techniques for non-defect production will help avoid the possibility of fault to slip within the apparel companies, where the order is released for full production (Koc, 2007; Feng, 2004; Liu et al., 2008; Tsai et al., 2009; Flegel and Brozova, 2011). In this way, the released sample can be delivered in the apparel company as a prototype, after which they will prepare the work order.

The analysis of the application of the TQM strategy showed that the implementation of the methodology for the total quality management increased the effectiveness and efficiency of the center. Textile companies that use the services of the center have reduced the time needed for the preparation of work orders by $20 \%$, increased utilization of fabrics by $5 \%$, and increased the productivity by $50 \%$. The service center helped achieving a quick and effective response to market demands and the textile enterprises significantly reduced the production costs and time of production. 


\section{Conclusion}

The creation of the "Textile-logistic center" is of great importance for Macedonia viewed from a marketing perspective, because it creates conditions for increasing competitiveness of the Macedonian textile manufacturers in the global market.

This center builds partnerships with Macedonian Apparel in preparatory activities for making models and optimization of business processes. In this way, the traditional models of the development of business processes were measured for errors, omissions and complaints, while in the center the proactive work is applied with the application of high technology and software packages that offer great accuracy in the preparation of templates.

The application of methods and techniques for non-defect work in this center contributes for greater efficiency and effectiveness in the company (Chepujnoska, 2009). The benefits of their application in practice have led to meeting the needs of the customers, strengthening the company's place in the market, employee satisfaction and improvement of the community. The daily practice of every employee does not only include control of the work, but employees are trained to act proactively, to be improved and not be burdened with error detection only.

For a successful implementation of the TQM strategy, learning new approaches to quality is necessary (Khir and Kai, 2012). Given the structure of employees (highly-educated and engineers), investment in new technology, new operating systems with new converters, ongoing training and information on new developments in the world are necessary in order to be compatible with the requirements of the customers. In this way, a high level of development in terms of providing quality at optimum cost, maintenance and conquering the market, as well as making a recognizable brand are being achieved.

\section{References}

Bhagwat, R., and Sharma, K.M. (2007). Performance Measurement of Supply Chain Management: A Balanced Scorecard Approach. Computers \& Industrial Engineering, (53): 43-62.

Chepujnoska, V. (2009). Quality Management -Theory, Science and Practice. Skopje: Faculty of Metallurgy.

Dale, B.G., and Lascelles, D.M. (2007). Levels of TQM Adoption. In B.G. Dale (ed.), Managing Quality (5th ed.). Oxford: Blackwell.

Evans, J.R. (2005). Total Quality: Management, Organization and Strategy (4th ed.). Mason, OH: Thomson South-Western.

Flegel, M., and Brozova, H. (2011, April). Fuzzy Decision-Making for Implementing ISO 9001 and/or ISO 14001. 12th WSEAS International Conference on Mathematics and Computers in Business and Economics (MCBE ,11), Romania.

Kulp, S.C.; Lee, H.L., and Ofek, E. (2004). Manufacturer Benefits from Information Integration with Retail Customers. Management Science, 50(4): 431-444.

Kaplan, S.R., and Norton, P.D. (2008). The Execution Premium: Linking Strategy to Operations for Competitive Advantages. Boston, USA: Harvard Business School Publishing Corporation.

Koc, T. (2007). The Impact of ISO 9000 Quality Management Systems on Manufacturing. Journal of Materials Processing Technology, 186(1-3): 207-213.

Khir, H., and Kai, C. (2012). An Integrated Modeling Method for Assessment of Quality Systems Applied to Aerospace Manufacturing Supply Chains. Journal of Intelligent Manufacturing, 23(4): 1365-1378. 
Lysons, K., and Farrington, B. (2006). Purchasing and Supply Chain Management. New York: Prentice Hall.

Lee, D.-E.; Lim, T-K., and Arditi, D. (2011). An Expert System for Auditing Quality Management Systems in Construction. Computer-Aided Civil and Infrastructure Engineering, 26(8): 612-631.

Mitreva, E. (2011). Model-integral Methodology for Successful Designing and Implementing of TQM System in Macedonian Companies. International Journal for Quality Research, 5(4): 255-260.

Mitreva, E.; Jakovlev, Z.; Koteski, C.; Kitanov, V., and Angelkova, T. (2012). Analysis of the Existing Management System in Macedonian Companies and the Necessity of Accepting the TQM Philosophy. International Journal of Pure and Applied Sciences and Technology, 8(2): 54-63.

Mitreva, E., and Filiposki, O. (2012). Proposal Methodology of the Subsystem-internal Standardization as Part of TQM System. International Journal for Quality Research, 6(3): 251-258.

Mabert, V.; Soni, A., and Venkataramanan, M. (2003). Enterprise Resource Planning: Managing the Implementation Process. European Journal of Operational Research, 146(2): 302-314.

Mitreva, E. (2012). The Need for Planning and Implementing Educational Activities in Macedonian Companies. International Journal for Quality Research, 6(2): 143-149.

Mitreva, E.; Taskov, N.; Kitanov, V.; Filiposki, O., and Dzaleva, T. (2013). The Need for Information System Design in Building a House of Quality. International Journal of Pure and Applied Sciences and Technology, 16(1): 26-33.

Mitreva, E. (2013). The Superior Customer's Value of the New Economy Implemented within Macedonian Companies. International Journal for Quality Research, 7(2): 215-220.

Tsai, W.-H., and Choua, W.-C. (2009). Selecting Management Systems for Sustainable Development in SMEs: A Novel Hybrid Model Based on DEMATEL, ANP, and ZOGP. Expert Systems with Applications, 36(2): 1444-1458.

\title{
VISUOTINĖS KOKYBĖS VADYBOS SISTEMOS PROJEKTAVIMAS IR DIEGIMAS TEKSTILĖS PRAMONĖJE
}

\author{
Elizabeta MITREVA \\ Nako TASKOV \\ „Goce Delčev“ universitetas, Makedonija
}

Santrauka. Šiame straipsnyje detaliai analizuojamas ir patvirtinamas poreikis sukurti ir ịdiegti visuotinès kokybès vadybos (toliau - VKV) sistemą Tekstilès logistikos centre, veikiančiame Makedonijos tekstilès pramonès šakoje. Remiantis autorių atlikta egzistuojančios kokybès valdymo sistemos analize buvo sukurta atitinkama metodologija kiekvienam VKV filosofijos elementui. Siekiant sukurti kokybès valdymo sistemą buvo pritaikytas Kokybės rato ir Pasekmių-priežasčių piramidinèje struktūroje modelis (QC-CE-Pyramid model), kurị naudojant sistema turi būti igyvendinama pasitelkiant Demingo ciklą (PDTV), taip pat buvo taikomas Ishikavos metodas (kas, ką, kur, kada), kuris taip pat tinka piramidinei kompanijos hierarchijai. VKV strategijos taikymo analizè parodè, kad visuotinès kokybès metodologijos igyvendinimas padidino centro efektyvumą ir ekonomiškumą. Tekstilès kompanijos, kurios naudojosi centro paslaugomis, 50 procentų sumažino laiką, reikalingą darbo užsakymams atlikti, padidino audinių utilizaciją 5 procentais ir padidino produktyvumą 50 procentų. Paslaugų centras padejjo pasiekti greitą ir efektyvų atsaką ị rinkos poreikius, o tekstilès kompanijos ženkliai sumažino produkcijos sąnaudas ir gamybos laiką.

Reikšminiai žodžiai: kokybė, visuotinès kokybès vadybos filosofija, QC-CE modelis, Pareto diagrama, Ishikavos metodas. 